\title{
Systematic review and meta-analysis of the prevalence of chronic fatigue syndrome/ myalgic encephalomyelitis (CFS/ME)
}

Eun-Jin Lim', Yo-Chan Ahn², Eun-Su Jang ${ }^{1}$, Si-Woo Lee ${ }^{3}$, Su-Hwa Lee ${ }^{4}$ and Chang-Gue Son ${ }^{1 *}$ (i)

\begin{abstract}
Background: Chronic fatigue syndrome/myalgic encephalomyelitis (CFS/ME) has been emerging as a significant health issue worldwide. This study aimed to systemically assess the prevalence of CFS/ME in various aspects of analyses for precise assessment.
\end{abstract}

Methods: We systematically searched prevalence of CFS/ME from public databases from 1980 to December 2018. Data were extracted according to 7 categories for analysis: study participants, gender and age of the participants, case definition, diagnostic method, publication year, and country of the study conducted. Prevalence data were collected and counted individually for studies adopted various case definitions. We analyzed and estimated prevalence rates in various angles: average prevalence, pooled prevalence and meta-analysis of all studies.

Results: A total of 1291 articles were initially identified, and 45 articles (46 studies, 56 prevalence data) were selected for this study. Total 1085,976 participants were enrolled from community-based survey $(540,901)$ and primary care sites $(545,075)$. The total average prevalence was $1.40 \pm 1.57 \%$, pooled prevalence $0.39 \%$, and meta-analysis $0.68 \%$ [95\% Cl 0.48-0.97]. The prevalence rates were varied by enrolled participants (gender, study participants, and population group), case definitions and diagnostic methods. For example, in the meta-analysis; women $(1.36 \% 95 \% \mathrm{Cl}$ 0.48-0.97]) vs. men (0.86\% [95\% Cl 0.48-0.97]), community-based samples (0.76\% [95\% Cl 0.53-1.10]) vs. primary care sites $(0.63 \%$ [ $95 \% \mathrm{Cl} 0.37-1.10])$, adults $\geq 18$ years $(0.65 \%$ [95\% Cl 0.43-0.99]) vs. children and adolescents $<18$ years (0.55\% [95\% Cl 0.22-1.35]), CDC-1994 (0.89\% [95\% Cl 0.60-1.33]) vs. Holmes (0.17\% [95\% Cl 0.06-0.49]), and interviews (1.14\% [95\% Cl 0.76-1.72]) vs. physician diagnosis (0.09\% [95\% Cl 0.05-0.13]), respectively.

Conclusions: This study comprehensively estimated the prevalence of CFS/ME; $0.89 \%$ according to the most commonly used case definition CDC-1994, with women approximately 1.5 to 2 folds higher than men in all categories. However, we observed the prevalence rates are widely varied particularly by case definitions and diagnostic methods. An objective diagnostic tool is urgently required for rigorous assessment of the prevalence of CFS/ME.

Keywords: Chronic fatigue syndrome, CFS, ME/CFS, Prevalence, Systematic review, Meta-analysis

\footnotetext{
*Correspondence: ckson@dju.ac.kr

${ }^{1}$ Institute of Bioscience and Integrative Medicine, Department of Korean Medicine, Daejeon University, 62 Daehak-ro, Dong-gu, Daejeon, Republic of Korea

Full list of author information is available at the end of the article
}

\begin{abstract}
Background
Chronic fatigue syndrome/myalgic encephalomyelitis (CFS/ME) is a debilitating illness that lacks a universally accepted case definition, cause, diagnosis, or treatment [1]. It is characterized by chronic fatigue lasting more than 6 months that is not alleviated by rest and is accompanied by complex and fluctuating symptoms of post exertion malaise (PEM), unrefreshing sleep, cognitive
\end{abstract}

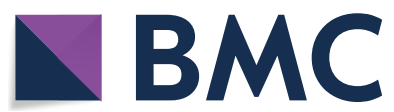

(c) The Author(s) 2020. This article is licensed under a Creative Commons Attribution 4.0 International License, which permits use, sharing, adaptation, distribution and reproduction in any medium or format, as long as you give appropriate credit to the original author(s) and the source, provide a link to the Creative Commons licence, and indicate if changes were made. The images or other third party material in this article are included in the article's Creative Commons licence, unless indicated otherwise in a credit line to the material. If material is not included in the article's Creative Commons licence and your intended use is not permitted by statutory regulation or exceeds the permitted use, you will need to obtain permission directly from the copyright holder. To view a copy of this licence, visit http://creativeco mmons.org/licenses/by/4.0/. The Creative Commons Public Domain Dedication waiver (http://creativecommons.org/publicdomain/ zero/1.0/) applies to the data made available in this article, unless otherwise stated in a credit line to the data. 
impairment, autonomic dysfunction, and/or pain in muscle or joint [2]. CFS/ME is known to be associated with poor health-related quality of life, worse than cancer, multiple sclerosis and stroke [3]. In fact, approximately 25 to $29 \%$ of CFS/ME patients were reported being house- or bed-bounded [4], also over half of the patients are unemployed [5], and only $19 \%$ work full-time [3].

Since this disorder was first recorded in 1934, numerous researchers have struggled to explore its biological etiologies, including viral infection and autoimmune dysregulation [6], neuroendocrine abnormality due to decreased hypothalamic-pituitary-adrenal (HPA) axis activity [7], and immune impairment caused by the abnormal production of cytokines [8]. Most recently, investigation of the interface between microglial activation and neuro-inflammation [9], the presence of widespread neuro-inflammation in the brains of CFS/ME patients [10], abnormal levels of serum TGF- $\beta$, a typical immune suppressive cytokine [11], and a nano-needle bioarray differentiating CFS/ME patients using blood samples [12], have provided new insights into the field. These studies may be promising; however, no therapeutics that can cure CFS/ME or objective diagnostic methods are available yet [13]. In addition, non-pharmacological therapies, such as cognitive behavior therapy (CBT) and graded exercise therapy (GET), and pharmacological trials, including immune modulator treatment, showed a lack of definitive efficacy for cure [13].

In worldwide statistics, approximately $1 \%$ of the population, 17 to 24 million people, suffer from this condition [14], which is likely to be as common as rheumatoid arthritis [15]. However, due to the lack of an objective diagnostic tool, an accurate estimation of prevalence has been challenging. Case definitions are the predominant tool for diagnosing CFS/ME at present. Since the development of the Centers for Disease Control and Prevention's (CDC) 1988 definition, a number of case definitions have been developed, including the latest definition of systemic exertion intolerance disease (SEID) proposed by the Institute of Medicine in 2015 [2]. Discrepancies in prevalence have been demonstrated in several studies according to the case definition used; estimated prevalence of $2.6 \%$ with the CDC- 1994 vs. $1.2 \%$ with the Holmes definition [16], and $0.42 \%$ with the CDC-1994 but increased by 2.8 times with the SEID definition [17].

Accurate prevalence rate and defining factor-related prevalence characteristics are essential for exploring the pathophysiological basis of any disease [18]. To date, several studies have estimated the overall prevalence rate of CFS/ME [19, 20]; however, they lacked in multi-analysis. This study aimed to provide comprehensive data on CFS/ ME prevalence from multiple aspects, which will be helpful in future studies of CFS/ME.

\section{Methods}

\section{Study design}

To investigate the prevalence of CFS/ME and explore its features, a primary population-based study from public databases was systematically reviewed and analyzed. The extracted and collected data were combined for a meta-analysis to analyze the consistency of the prevalence. This systematic review has been registered in the PROSPERO database (CRD42019141250).

\section{Data sources and eligibility criteria}

We searched research papers published from 1980 to December 2018, as the known first case definition published was in 1986 [21]. The data were collected from the databases PubMed, the Cochrane Library, EBSCOhost (CINAHL, Medline), Google Scholar, and handsearched for relevant references. The search concepts were chronic fatigue syndrome, myalgic encephalomyelitis, prevalence, and clinical study, and the search keyword was "(Chronic fatigue syndrome [MeSH term]) AND Prevalence".

Papers were screened using the following inclusion criteria: (a) prevalence study of chronic fatigue syndrome and/or myalgic encephalomyelitis, (b) clinical study, and (c) population-based study. The initial assessment was made by considering the inclusion criteria and reading the title and abstract. Articles that met the criteria were thoroughly read in full and screened according to the exclusion criteria. The exclusion criteria were as follows: (a) nonclinical-based studies, (b) studies on clinical features or symptoms of CFS/ME, (c) randomized controlled studies, (d) studies focusing on biological aspects of CFS/ME, (e) studies on psychological/psychiatric issues associated with CFS/ME, (f) studies on treatment or therapeutic aspects (e.g., the use of supplements) of CFS/ME, and (g) studies with fewer than 500 participants (Fig. 1).

\section{Review process and data extraction}

Two authors initially searched and selected the eligible articles according to the above inclusion and exclusion criteria. From the selected articles, data pertaining to prevalence, the number of participants and CFS/ME patients, gender of the participants, population group, study participants, publication year, country, case definition, and diagnostic method were extracted. In particular, case definitions were extracted and treated as individual prevalence data for studies that applied multiple case definitions. The selection of articles, the clarity of the extracted data, and the final decision was based upon the consensus of our research team. 


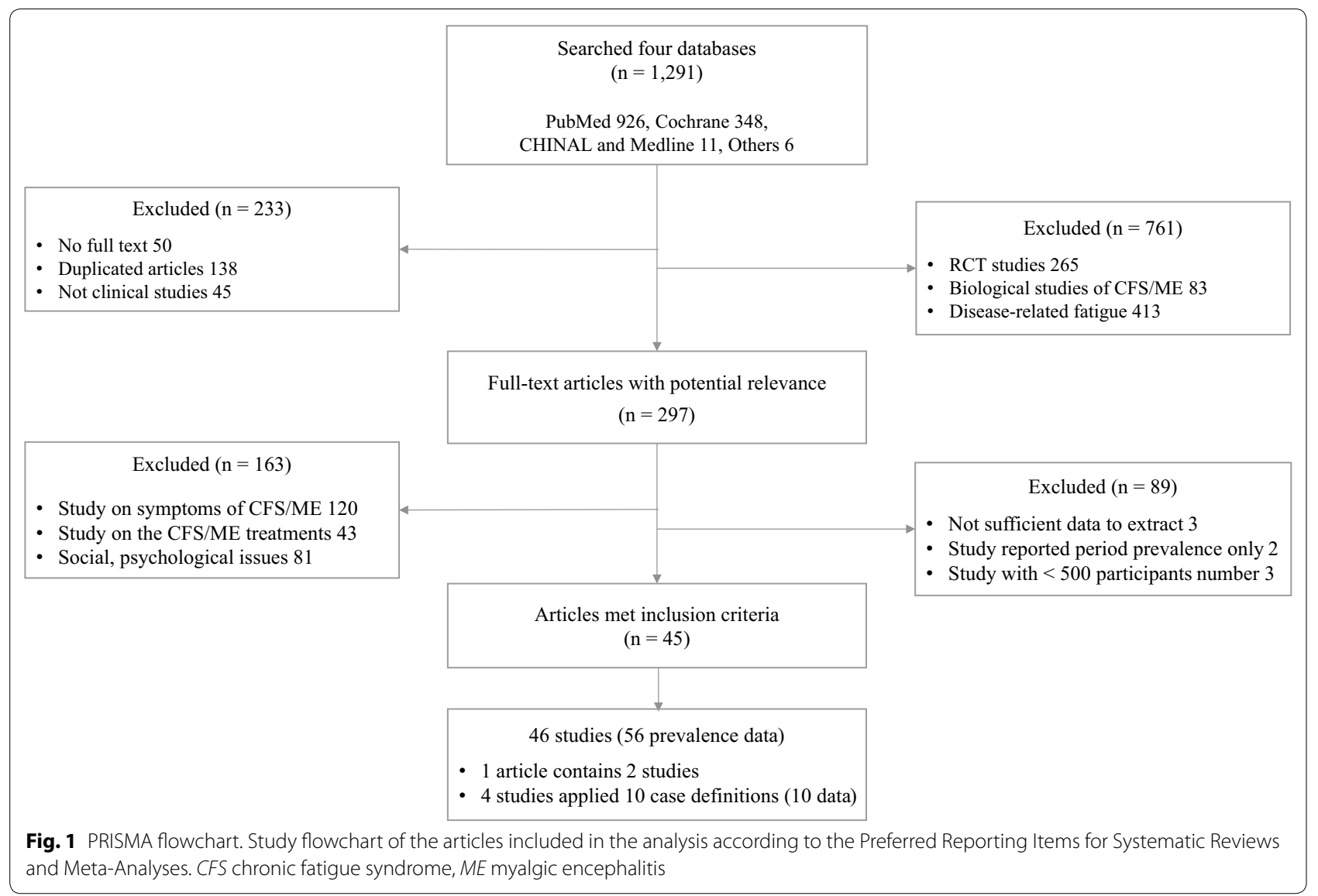

\section{Data coding and synthesis}

The data from each article were subgrouped as follows: the age of the participants; publication year (19902000, 2001-2010, 2010-2018); study participants (community, primary care); population group (general population, children and adolescents, specific population); country (Western, Asian, others); 8 case definitions: CDC-1994 (Centers for Disease Control and Prevention) [22], Holmes [23], Oxford [24], Australian [25], and others, including ECD (epidemiological case definition) [26], CCC (Canadian Consensus Criteria) [27], PVES (post viral exhaustion syndrome) [28], NICE guidelines (National Institute for Health and Care Excellence) [29], and diagnostic methods (interviews with/without medical test, physician diagnosis, medical record). These data were coded as categorical variables and synthesized in a coding book developed by our research team. The number of participants and CFS/ ME patients from the selected articles were arranged to compare community samples vs. primary care samples and males vs. females to estimate the number of populations and the prevalence. The codes and details of the 45 selected articles are provided in the supplementary data (Additional file 1).

\section{Statistical analysis}

A meta-analysis using the random effects model by the $R$ program was conducted to account for the heterogeneity of the data: prevalence with subgroup analysis was applied. Heterogeneity indicates dissimilarity in the individual study results. $I^{2}$ quantifies the effect of heterogeneity; that is, the proportion of interstudy variability [30, 31].

\section{Results}

\section{Characteristics of the included studies}

From four major public databases, a total of 1291 articles were initially identified, and 45 articles finally met the inclusion criteria for this study. The first study of selected articles was reported in 1990 [25], and the latest one was in 2018 [32]. Forty-six studies (one article contained two studies) were conducted in 13 countries (41 prospectively and 5 retrospectively). Four studies applied multiple case definitions ( 2 studies applied 4 case definitions, 2 studies applied 3 case definitions), providing a total of 56 prevalence data (Fig. 1). The total number of participants was 1085,976 from 30 community-based studies (33 data, $\mathrm{n}=540,901)$ and 16 primary care studies (23 data, $\mathrm{n}=545,075)$. Thirty-four studies (44 
data) focused on the general population ( $\mathrm{n}=956,526$, age $\geq 18$ years), 7 focused on children and adolescents $(\mathrm{n}=117,307,<18$ years $)$, and 5 focused on a particular population ( $\mathrm{n}=12,143$; nurses, 2 ; company employees, 1 ; livestock employees, 1; Gulf War veterans, 1). The average number of participants in each study was $23,608 \pm 48,092$ $( \pm \mathrm{SD})$. Of the 46 studies, 21 studies (24 data) reported gender-related information (males, $\mathrm{n}=62,070$; females, $\mathrm{n}=68,772)$ (Table 1$)$.

A total of 8 case definitions were adopted in 46 studies (56 data); the most frequently used definitions were CDC-1994 (34 data) and Holmes (8 data). The majority of the studies (37 studies/45 data) used interview-based diagnoses with/without medical tests, and the remaining studies ( 9 studies/11 data) were based on a physicians' diagnosis/determination and medical record reviews. The average age of all participants except children and adolescents, based on the mean of the means/median ages reported in the articles, was $40.0 \pm 9.9$ years (Table 1 ).

\section{Overview of CFS/ME prevalence}

The average prevalence of CFS/ME based on the 56 prevalence data reported was $1.40 \pm 1.57 \%$ (95\% CI: $0.98-1.82$ ), and the pooled prevalence was $0.39 \%$ (5370 CFS/ME patients of 1387,787 participants) (Table 2). The meta-analysis yielded an estimate of $0.68 \%$ (95\% CI: 0.480.97 ) with high heterogeneity $I^{2}=99.4 \%$ (Table 3, Fig. 2). For the general population (excluding data for children and adolescents and specific populations), the average prevalence was $1.45 \pm 1.68 \%$ (95\% CI: $1.01-1.89$ ) and $0.38 \%$ (4724 CFS/ME patients of 1258,337 participants) and $0.65 \%$ (95\% CI: 0.43-0.99) in the meta-analysis based on 44 prevalence data (Tables 2 and 3, and Fig. 3).

Regarding gender-related differences, 24 data (from 21 studies that included information about gender) indicated an approximately 2.0-fold preponderance of females of $2.24 \pm 2.59 \%$ vs. $1.11 \pm 1.05 \%$ for the total population and 2.83 vs. $1.39 \%$ for the general population; the prevalence was 1.5 -fold higher according to the metaanalysis, 1.36 vs. $0.89 \%$ (Table 2 and 3, Fig. 4).

\section{Prevalence by study participants}

When we analyzed the CFS/ME prevalence according to study participants (community-based sample vs. primary care sample), the 30 community studies (33 data) showed a prevalence of $1.56 \pm 1.80 \%$ (95\% CI: $1.08-2.04$ ), and the 16 primary care studies (23 data) showed a prevalence of $1.16 \pm 1.13 \%$ (95\% CI: 0.86-1.46). A higher prevalence in community studies was also observed in the pooled prevalence results of $0.73 \%$ (4014 CFS/ME patients out of 548,461 participants) vs. $0.21 \%$ (1739 out of 839,326 ) and in the meta-analysis findings of $0.76 \%$ (95\% CI: $0.53-$ $1.10)$ vs. $0.63 \%$ (95\% CI: $0.37-1.10$ ), respectively (Table 2 ,
3, and Additional file 2). From the results of 21 studies (24 data) with known gender-related data, the prevalence of female preponderates in both community $(2.31 \%$ vs. $1.03 \%)$ and primary care settings (1.96 vs. $1.39 \%)$ (Table 2).

\section{Prevalence by study population group}

The study population was divided into 3 groups: general population ( $\mathrm{n}=956,526, \geq 18$ years), children and adolescents $(\mathrm{n}=117,307,<18$ years), and specific populations $(\mathrm{n}=12,143$, e.g., nurses, Gulf War veterans) (Table 1$)$. The prevalence in the general population (1.45\%) and in specific populations $(1.62 \%)$ were higher than that in children and adolescents $(0.89 \%)$ (Table 2 ). The meta-analysis indicated prevalence of $0.65 \%$ (95\% CI: $0.43-0.99$ ) in the general population, $1.31 \%$ (95\% CI: $0.61-2.78$ ) in specific populations and $0.55 \%$ (95\% CI: $0.22-1.35$ ) in children and adolescents (Table 3, Fig. 3, and Additional file 3). In the general population, a female predominance was shown in both the averaged ( $2.83 \pm 2.61$ vs. $1.39 \pm 1.05 \%)$, and the meta-analysis (1.36\%, 95\% CI: $0.91-2.04$ vs. 0.89 , 95\% CI: 0.60-1.32) (Table 2, 3 and Fig. 4).

\section{Prevalence by case definitions}

Eight case definitions [22-29] were adopted for 44 studies (54 data); 2 studies used unknown case definitions. The total prevalence was notably different according to case definition:, the prevalence was the highest with Australian $(2.52 \pm 2.99 \%)$, then in descending order, Oxford $(1.73 \pm 1.35 \%)$, CDC-1994 (1.46 $\pm 1.34 \%)$ and Holmes definitions $(0.34 \pm 0.40 \%)$, but in the meta-analysis, the orders changed to Oxford (1.41\%, 95\% CI: 0.68-2.93), CDC-1994 (0.89\%, 95\% CI: 0.60-1.33), Australian (0.79\%, 95\% CI: 0.05-12.55) and Holmes (0.17\%, 95\% CI: $0.06-$ 0.49) (Table 2, 3 and Additional file 4, 5).

\section{Prevalence by diagnostic method}

In this study, the diagnostic methods could be classified into four groups, and the prevalence data differed significantly among them $(P<0.05)$, as follows: interview without a medical test (survey and/or questionnaire, 19 studies, averaged prevalence $2.03 \pm 2.13 \%$ ), interview with a medical test (18 studies, $1.17 \pm 0.77 \%$ ), review of medical records (5 studies, $1.25 \pm 1.00 \%$ ) and physician diagnosis (4 studies, $0.10 \pm 0.05 \%$ ) (Table 1,2 ).

The meta-analysis also showed different prevalence, as follows: interviews without medical tests $(1.14 \%, 95 \%$ CI: $0.76-1.72)$, interviews with medical tests $(0.95 \% 95 \% \mathrm{CI}$ : $0.69-1.31)$, medical record review $(0.52 \% 95 \%$ CI: $0.16-$ $1.71)$, and physician diagnoses $(0.09 \%, 95 \% \mathrm{CI}$ : $0.05-0.13)$ (Table 3, and Additional file 6, 7). 
Table 1 Characteristics of studies on the prevalence of CFS/ME ( \pm SD)

\begin{tabular}{|c|c|c|c|c|c|c|}
\hline Group & Community & & Primary care & & Total & \\
\hline Number of articles included (\%) & $30(67)$ & & $15(33)$ & & $45(100)$ & \\
\hline Number of studies included $(\%)$ & $30(65)$ & & $16(35)$ & & $46(100)$ & \\
\hline Prospective & $25(54)$ & & $16(35)$ & & $41(89)$ & \\
\hline Retrospective & $4(9)$ & & $1(2)$ & & $5(11)$ & \\
\hline Number of prevalence datab $(\%)$ & $33(59)$ & & $23(41)$ & & $56(100)$ & \\
\hline Total number of participants & 540,901 & & 545,075 & & 1085,976 & \\
\hline Mean N. of participants & $18,030 \pm 38,094$ & & $34,067 \pm 61,325$ & & $23,608 \pm 48,092$ & \\
\hline Total number of known sex & 120,765 & & 10,077 & & 130,842 & \\
\hline Male & 58,752 & & 3318 & & 62,070 & \\
\hline Female & 62,013 & & 6759 & & 68,772 & \\
\hline M:F ratio & $48: 52$ & & $25: 75$ & & $45: 55$ & \\
\hline Mean age of participants ${ }^{d}$ & $41.1 \pm 11.3$ & & $38.0 \pm 6.5$ & & $40.0 \pm 9.9$ & \\
\hline Male & $41.1 \pm 11.3$ & & $38.0 \pm 6.8$ & & $39.9 \pm 10.0$ & \\
\hline Female & $41.2 \pm 11.4$ & & $38.1 \pm 6.1$ & & $40.0 \pm 9.8$ & \\
\hline \multicolumn{7}{|c|}{$N$. of (studies)/prevalence data by subgroup ( $N$. of participants) } \\
\hline \multicolumn{7}{|l|}{ Publication year } \\
\hline 1990-2000 & 8 & $(177,201)$ & 15 & $(318,391)$ & $(18) / 23$ & $(495,592)$ \\
\hline $2001-2010$ & 19 & $(86,512)$ & 4 & (9895) & $(20) / 23$ & $(96,407)$ \\
\hline $2011-2018$ & 6 & $(277,188)$ & 4 & $(216,789)$ & $(8) / 10$ & $(493,977)$ \\
\hline \multicolumn{7}{|l|}{ Population group } \\
\hline General population ( $\geq 18$ years) & 24 & $(489,961)$ & 20 & $(466,565)$ & $(34) / 44$ & $(956,526)$ \\
\hline Children/adolescents (<18 years) & 6 & $(43,671)$ & 1 & $(73,636)$ & $(7) / 7$ & $(117,307)$ \\
\hline Specific population ${ }^{\mathrm{e}}$ & 3 & (7269) & 2 & (4874) & $(5) / 5$ & $(12,143)$ \\
\hline Case definition (8 case definitions) & 23 & $(339,192)$ & 11 & $(298,739)$ & 34 & $(637,931)$ \\
\hline CDC-1994 [22] & 4 & $(20,037)$ & 4 & $(27,454)$ & 8 & $(47,491)$ \\
\hline Holmes [23] & 2 & $(116,520)$ & 2 & $(2980)$ & 4 & $(119,500)$ \\
\hline Australian [25] & 2 & (3215) & 2 & $(2980)$ & 4 & $(6195)$ \\
\hline Oxford [24] & 1 & $(10,396)$ & 3 & $(505,299)$ & 4 & $(515,695)$ \\
\hline CCC [27] ECD [26] PVES [28] NICE [29] ${ }^{\mathrm{f}} \mathrm{N} / \mathrm{A}^{\mathrm{g}}$ & 1 & $(59,101)$ & 1 & $(1874)$ & 2 & $(60,975)$ \\
\hline \multicolumn{7}{|l|}{ Country (13 countries) } \\
\hline Western & 27 & $(516,617)$ & 17 & $(473,009)$ & $(34) / 44$ & $(989,626)$ \\
\hline Asian & 5 & $(23,197)$ & 5 & $(70,192)$ & $(10) / 10$ & $(93,389)$ \\
\hline Others $^{h}$ & 1 & $(1087)$ & 1 & (1874) & $(2) / 2$ & $(2961)$ \\
\hline \multicolumn{7}{|l|}{ Diagnostic method } \\
\hline Interview (medical test -) & 19 & $(111,943)$ & 3 & $(68,848)$ & $(19) / 22$ & $(180,791)$ \\
\hline Interview (medical test + ) & 9 & $(57,339)$ & 14 & $(17,445)$ & $(18) / 23$ & $(74,784)$ \\
\hline Physician diagnosis & 1 & $(114,000)$ & 5 & $(435,782)$ & $(4) / 6$ & $(549,782)$ \\
\hline Medical records & 4 & $(257,619)$ & 1 & $(23,000)$ & $(5) / 5$ & $(280,619)$ \\
\hline
\end{tabular}

a The number of studies is larger $(n=46)$ than the number of article as one article included two studies

b Some articles included multiple applications of case definitions; thus, the number is larger than the total number of studies

c Twenty-one studies (24 prevalence data points) included information about participant sex

$d$ The mean age of the participants whose sex was known (12 studies) was estimated using either the reported mean age for each sex or the mean age for both. Children and adolescents were excluded

e Specific groups included nurses, Gulf War veterans, livestock workers, company employees, etc

f CCC, Canadian Consensus Criteria; ECD, epidemiological case definition; PVES, post viral exhaustion syndrome; and NICE, National Institute for Health and Care Excellence guideline 2007

g Two N/A cases had no verification of case definition or defined criteria

${ }^{h}$ Other countries included India and Nigeria 
Table 2 Prevalence of CFS/ME by subgroup ( \pm SD)

\begin{tabular}{|c|c|c|c|c|}
\hline \multirow[t]{2}{*}{ Group $^{a}$} & Male (\%) & Female (\%) & Total $(\%, M / F)$ & \multirow{2}{*}{$\begin{array}{l}\text { Total (\%) } \\
\text { (46 studies/56 data) }\end{array}$} \\
\hline & \multicolumn{3}{|c|}{ (21 studies/24 data) } & \\
\hline Average prevalence of all studies & $1.11 \pm 1.05$ & $2.24 \pm 2.59$ & $1.67 \pm 2.06$ & $1.40 \pm 1.57$ \\
\hline Pooled prevalence of all studies (Total N. of CFS/N. of participants ${ }^{b}$ ) & $0.74(451 / 61,069)$ & $1.92(1308 / 68,124)$ & $1.37(1778 / 129,780)$ & $0.39(5370 / 1387,787)$ \\
\hline $\begin{array}{l}\text { Pooled prevalence of the general population (N. of adult CFS/N. of } \\
\text { adult participants) }\end{array}$ & $0.75(451 / 60,432)$ & $1.92(1304 / 67,790)$ & $1.38(1774 / 128,809)$ & $0.38(4724 / 1258,337)$ \\
\hline Mean age of CFS patients (12 studies) & $39.3 \pm 7.8$ & $39.1 \pm 7.6$ & $40.4 \pm 7.7$ & $40.4 \pm 7.7$ \\
\hline \multicolumn{5}{|l|}{ Prevalence by subgroup ( $N$. of studies that reported sex) } \\
\hline \multicolumn{5}{|l|}{ Study participants } \\
\hline Community (16) & $1.03 \pm 1.13$ & $2.31 \pm 2.88$ & $1.67 \pm 2.28$ & $1.56 \pm 1.80$ \\
\hline Pooled prevalence (N. of CFS/N. of participants ${ }^{b}$ ) & $0.70(404 / 57,751)$ & $1.94(1190 / 61,365)$ & $1.34(1594 / 119,116)$ & $0.73(4014 / 548,461)$ \\
\hline Primary care (5) & $1.39 \pm 0.56$ & $1.96 \pm 0.74$ & $1.68 \pm 0.72$ & $1.16 \pm 1.13$ \\
\hline Pooled prevalence ( $N$. of CFS/N. of participants ${ }^{b}$ ) & $1.42(47 / 3318)$ & $1.75(118 / 6759)$ & $1.64(165 / 10,077)$ & $0.21(1739 / 839,326)$ \\
\hline \multicolumn{5}{|l|}{ Publication year } \\
\hline 1990-2000 (9) & $0.62 \pm 0.58$ & $1.26 \pm 1.42$ & $0.94 \pm 1.13$ & $0.96 \pm 0.91$ \\
\hline $2001-2010(10)$ & $1.35 \pm 1.18$ & $2.99 \pm 3.11$ & $2.17 \pm 2.49$ & $2.08 \pm 2.01$ \\
\hline $2011-2018(2)$ & $1.75 \pm 0.83$ & $1.78 \pm 0.71$ & $1.76 \pm 0.77$ & $0.84 \pm 0.86$ \\
\hline \multicolumn{5}{|l|}{ Population group } \\
\hline General population ( $\geq 18$ years) (19) & $1.39 \pm 1.05$ & $2.83 \pm 2.61$ & $2.11 \pm 2.07$ & $1.45 \pm 1.68$ \\
\hline Children/adolescents (<18 years) $(0)$ & - & - & - & $0.89 \pm 0.82$ \\
\hline Specific population $^{c}(1)$ & 0.12 & 0.06 & $0.09 \pm 0.03$ & $1.62 \pm 1.17$ \\
\hline \multicolumn{5}{|l|}{ Case definition (8 case definitions) } \\
\hline CDC-1994 [22] (16) & $1.24 \pm 1.04$ & $2.61 \pm 2.75$ & $1.93 \pm 2.19$ & $1.46 \pm 1.34$ \\
\hline Holmes [23] (4) & $0.07 \pm 0.05$ & $0.14 \pm 0.15$ & $0.11 \pm 0.12$ & $0.34 \pm 0.40$ \\
\hline Australian [25] (1) & 2.65 & 5.23 & $3.94 \pm 1.29$ & $2.52 \pm 2.99$ \\
\hline Oxford [24] (2) & $1.23 \pm 0.64$ & $1.76 \pm 1.22$ & $1.51 \pm 1.00$ & $1.73 \pm 1.35$ \\
\hline CCC [27] ECD [26] PVES [28] NICE [29] ${ }^{\mathrm{d}}(0)$ & - & - & - & $0.53 \pm 0.77$ \\
\hline \multicolumn{5}{|l|}{ Country (13 countries) } \\
\hline Western (12) & $1.14 \pm 0.97$ & $2.40 \pm 2.86$ & $1.77 \pm 2.22$ & $1.32 \pm 1.45$ \\
\hline Asian (8) & $1.23 \pm 2.92$ & $2.06 \pm 1.85$ & $1.65 \pm 1.64$ & $1.51 \pm 1.74$ \\
\hline Others $^{\mathrm{e}}(1)$ & 0.11 & 0.50 & $0.31 \pm 0.20$ & $2.65 \pm 2.37$ \\
\hline \multicolumn{5}{|l|}{ Diagnostic method } \\
\hline Interview (medical test -) (9) & $1.70 \pm 1.21$ & $4.32 \pm 3.24$ & $3.01 \pm 2.63$ & $2.03 \pm 2.13$ \\
\hline Interview (medical test + ) (10) & $0.86 \pm 0.70$ & $1.23 \pm 0.93$ & $1.05 \pm 0.84$ & $1.17 \pm 0.77$ \\
\hline Physician diagnosis (0) & - & - & - & $0.10 \pm 0.05$ \\
\hline Medical records (1) & 2.57 & 2.49 & $2.53 \pm 0.06$ & $1.25 \pm 1.00$ \\
\hline
\end{tabular}

a The prevalence by sex was estimated from studies that reported both the number of participants and the number with CFS

b Participant number was applied to individual prevalence data for the studies with multiple case definitions

c Specific groups included nurses, Gulf War veterans, livestock workers, company employees, etc

d CCC, Canadian Consensus Criteria; ECD, epidemiological case definition; PVES, post viral exhaustion syndrome; and NICE, National Institute for Health and Care Excellence guideline 2007; two studies with no verification of case definition and defined criteria were excluded

e Other countries included India and Nigeria

\section{Prevalence by country and publication year}

The majority of the studies were conducted in Western countries (34 studies/44 prevalence data from 8 countries, 989,626 participants), followed by Asian countries (10 studies/10 data, 3 countries, 93,389), and others (2 studies/2 data, 2 countries, 2961). The total prevalence reported for Western and Asian populations were comparable $(1.32 \pm 1.45 \%$ vs. $1.51 \pm 1.74 \%)$ (Tables 1 , 2 and Additional file 1). The majority (38 of 46) of the studies were published between 1990 and 2010. Of those studies, 10 (of 18) studies were for primary care population conducted in 1990s, whereas 16 (of 20) for community in 2000s. More studies on community-based were conducted in 2000s than 1990s (Table 1). The total 
Table 3 Meta-analysis results for the prevalence of CFS/ME

\begin{tabular}{|c|c|c|c|c|c|c|}
\hline \multirow[t]{2}{*}{ Group } & \multirow[t]{2}{*}{ N. of data ${ }^{a}$} & \multicolumn{2}{|c|}{ Random effects model (\%) } & \multicolumn{3}{|c|}{ Heterogeneity $(P<0.01, P=0 \%)$} \\
\hline & & Prevalence & $95 \% \mathrm{Cl}$ & $Q$ & $T^{2}$ & $I^{2}(\%)$ \\
\hline Total & 56 & 0.68 & {$[0.48 ; 0.97]$} & 8602.90 & 1.7199 & 99.4 \\
\hline \multicolumn{7}{|l|}{ Sex } \\
\hline Male & 24 & 0.86 & {$[0.58 ; 1.27]$} & 279.89 & 0.6666 & 91.8 \\
\hline Female & 24 & 1.36 & {$[0.91 ; 2.02]$} & 822.64 & 0.8003 & 97.2 \\
\hline Total & 48 & 1.04 & {$[0.76 ; 1.41]$} & 1481.76 & 0.9471 & 96.8 \\
\hline \multicolumn{7}{|l|}{ Study participants } \\
\hline Community & 33 & 0.76 & {$[0.53 ; 1.10]$} & 3286.47 & 1.0363 & 99.0 \\
\hline Primary care & 23 & 0.63 & {$[0.37 ; 1.10]$} & 2732.10 & 1.7745 & 99.2 \\
\hline \multicolumn{7}{|l|}{ Population group } \\
\hline \multicolumn{7}{|l|}{ General population ( $\geq 18$ years) } \\
\hline Male & 23 & 0.89 & {$[0.60 ; 1.32]$} & 276.23 & 0.6607 & 92.0 \\
\hline Female & 23 & 1.36 & {$[0.91 ; 2.04]$} & 818.30 & 0.8009 & 97.3 \\
\hline Total & 44 & 0.65 & {$[0.43 ; 0.99]$} & 7717.65 & 1.8518 & 99.4 \\
\hline Children/adolescents (<18 years) & 7 & 0.55 & {$[0.22 ; 1.35]$} & 538.13 & 1.4319 & 98.9 \\
\hline Specific population & 5 & 1.31 & {$[0.61 ; 2.78]$} & 80.54 & 0.6657 & 95.0 \\
\hline \multicolumn{7}{|l|}{ Case definition } \\
\hline CDC-1994 [22] & 34 & 0.89 & {$[0.60 ; 1.33]$} & 3871.64 & 1.3691 & 99.1 \\
\hline Holmes [23] & 8 & 0.17 & {$[0.06 ; 0.49]$} & 101.72 & 1.8890 & 93.1 \\
\hline Australian [25] & 4 & 0.79 & {$[0.05 ; 12.55]$} & 1002.43 & 7.8860 & 99.7 \\
\hline Oxford [24] & 4 & 1.41 & {$[0.68 ; 2.93]$} & 35.17 & 0.4468 & 91.5 \\
\hline CCC [27] ECD [26] PVES [28] NICE [29] ${ }^{\mathrm{b}}$ & 4 & 0.17 & {$[0.04 ; 0.83]$} & 1200.67 & 2.5864 & 99.8 \\
\hline \multicolumn{7}{|l|}{ Diagnostic method } \\
\hline Interview (medical test -) & 22 & 1.14 & {$[0.76 ; 1.72]$} & 1675.91 & 0.8269 & 98.7 \\
\hline Interview(medical test + ) & 23 & 0.95 & {$[0.69 ; 1.31]$} & 365.72 & 0.5208 & 94.0 \\
\hline Physician diagnosis & 6 & 0.09 & {$[0.05 ; 0.13]$} & 200.49 & 0.2952 & 97.5 \\
\hline Medical records & 5 & 0.52 & {$[0.16 ; 1.71]$} & 1197.28 & 1.8360 & 99.7 \\
\hline
\end{tabular}

Refer to supplementary Additional file: Figs. 1, 2, 3, 4, 5, 6, 7

a Total number of prevalence data points

b CCC, Canadian Consensus Criteria; ECD, epidemiological case definition; PVES, post viral exhaustion syndrome; and NICE, National Institute for Health and Care Excellence guideline 2007; two studies with no verification of case definition and defined criteria were excluded

prevalence in $2000 \mathrm{~s}(2.08 \pm 2.01)$ was approximately twofold higher than 1990s $(0.96 \pm 0.91)$ (Table 2).

\section{Discussion}

This systematic review and meta-analysis aimed to provide a reviewed estimate of the prevalence of CFS/ME worldwide. We combined the 56 data from 46 studies conducted in 13 countries since prevalence study was first published in 1990 for the Australian general population [25]. The prevalence of CFS/ME varies widely, from 0.01 [33] to $7.62 \%$ [34], as indicated by the high heterogeneity in the meta-analysis, $I^{2}=99.4 \%$ (Table 3 and Additional file 1). We considered the matter from various angles to investigate the inconsistency of the prevalence data. Thus, we synthesized the prevalence data, estimated the average, the pooled prevalence based on the number of participants and CFS/ME patients, and assessed the prevalence with heterogeneity by using meta-analysis according to the following subgroups: gender, study participants, population group, case definition, diagnostic method, and country.

The terms and case definitions for CFS and ME have been reformulated according to perceptions of the disorder and study groups throughout the history of the disorder (Fig. 5). Briefly, this condition was thought to be a new type of poliomyelitis in the 1930s and was then perceived as hysteria caused by psychological issues in the 1970 s and early 1980s. Since Ramsay M. defined the first diagnostic criteria for ME in 1986, characterizing it as a unique form of muscle fatigability triggered by a virus [2], various terminologies and case definitions have been proposed. In 1988, the CDC first proposed the new term CFS (Holmes criteria) instead of "Chronic Epstein-Barr 


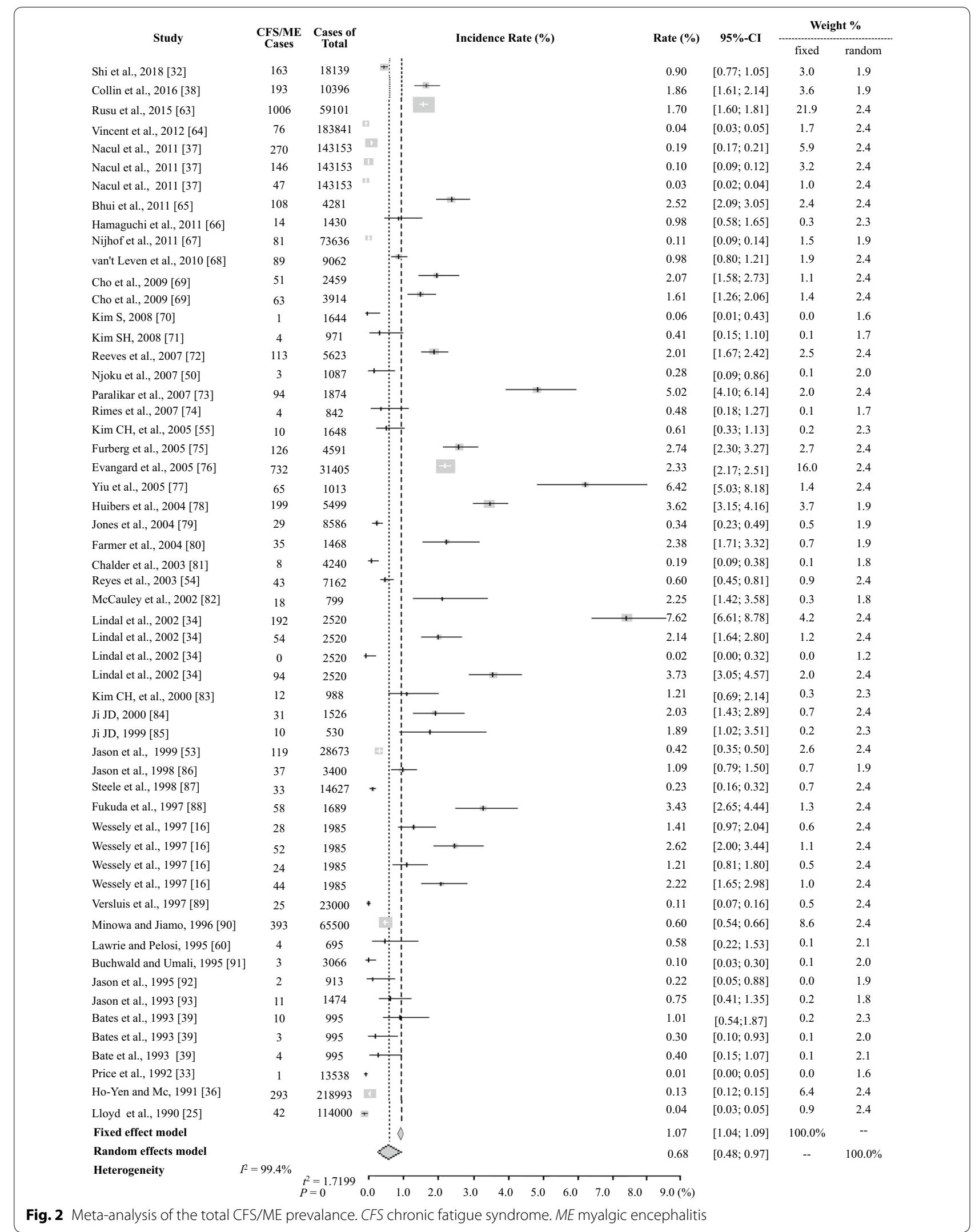




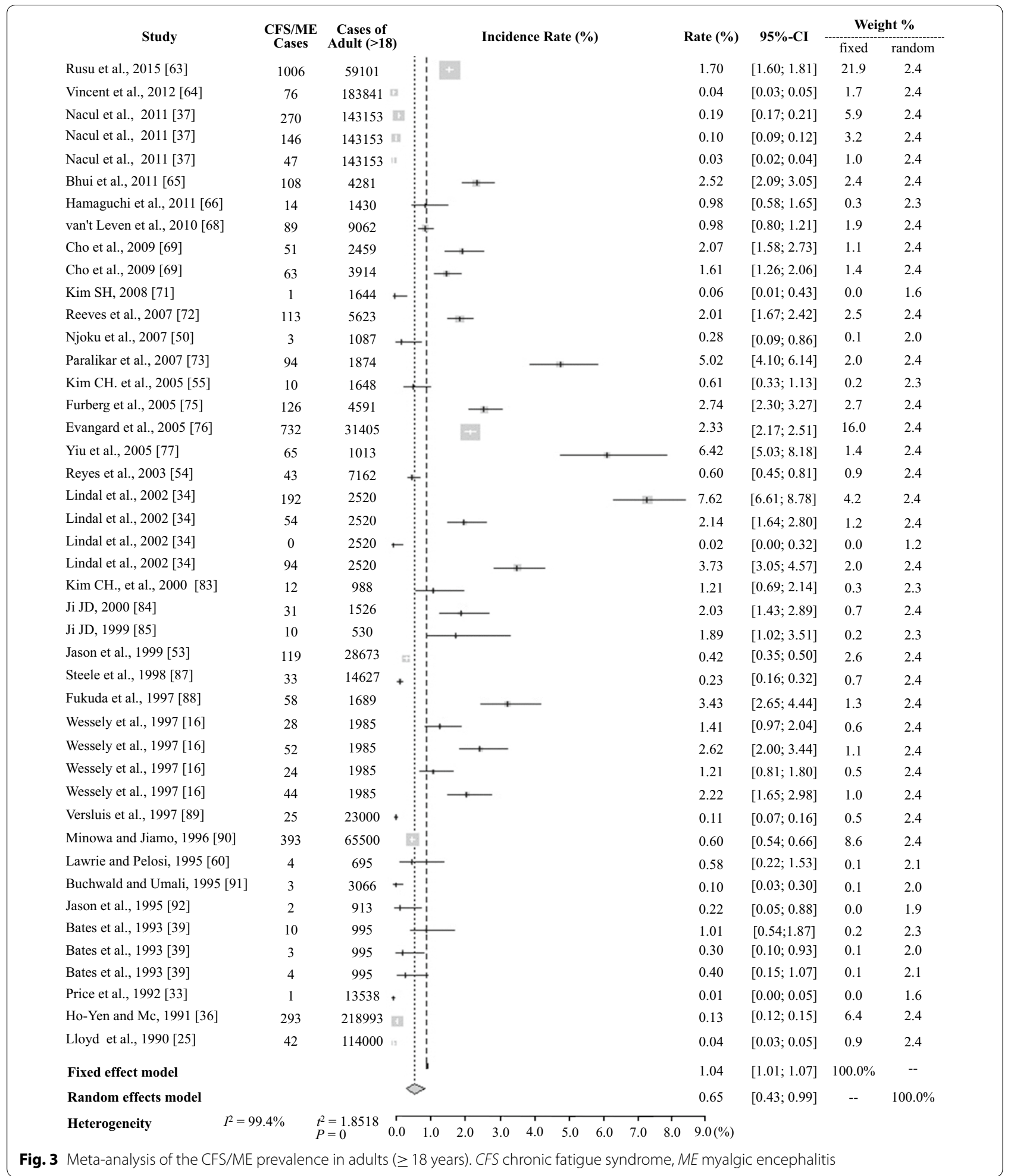

virus syndrome" to more accurately describe the symptom complex requiring 2 major with 8 of 11 minor symptoms, and to emphasize recurrent debilitating fatigue [23]. The term was revised by Fukuda K. in 1994 (Fukuda criteria) [22]. In 2003, CFS/ME, an umbrella term that covers both ME and CFS symptom criteria, was used in the CCC definition [27], while the ICC reformulated the definition and readopted the term ME in 2011 [35], and 


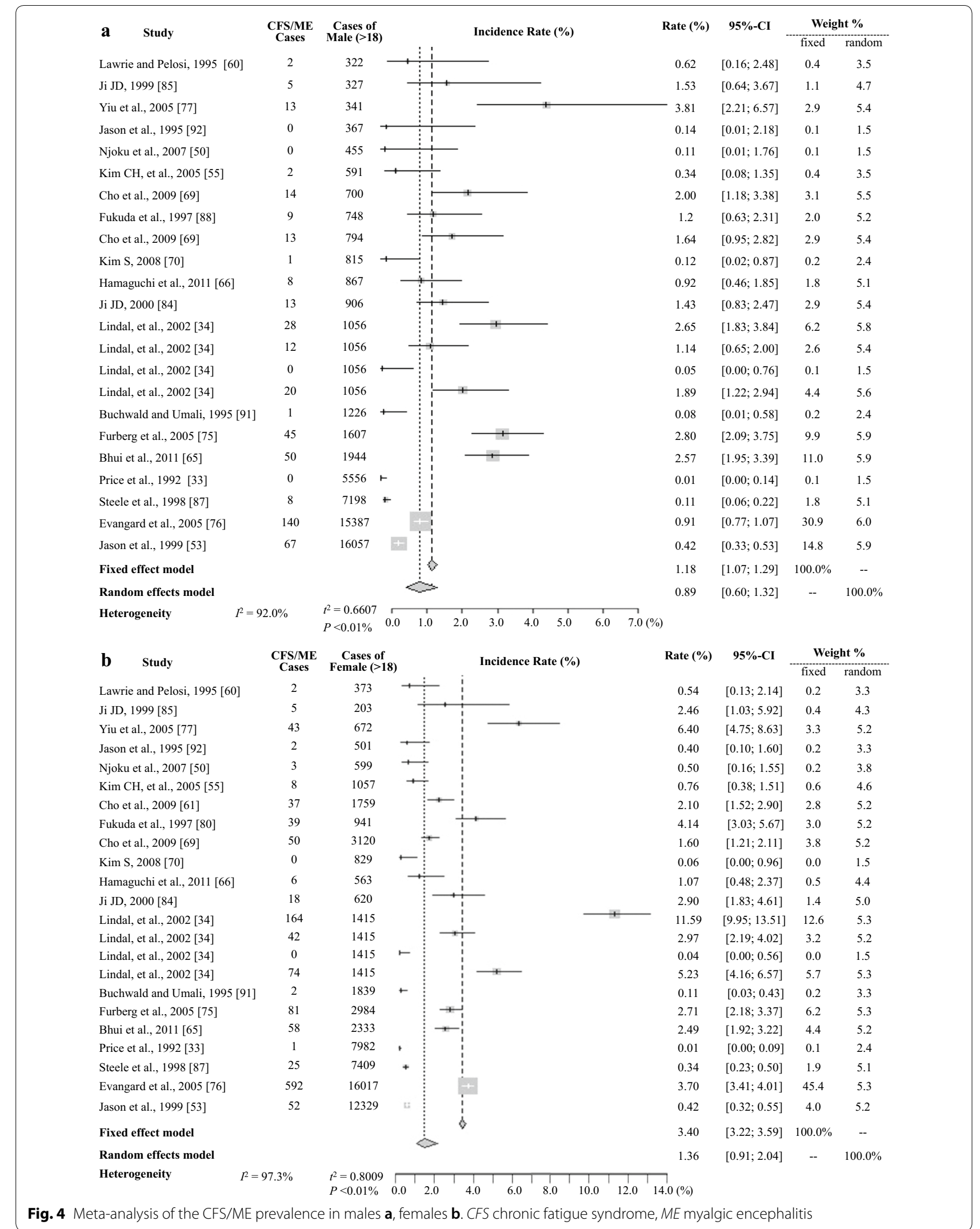




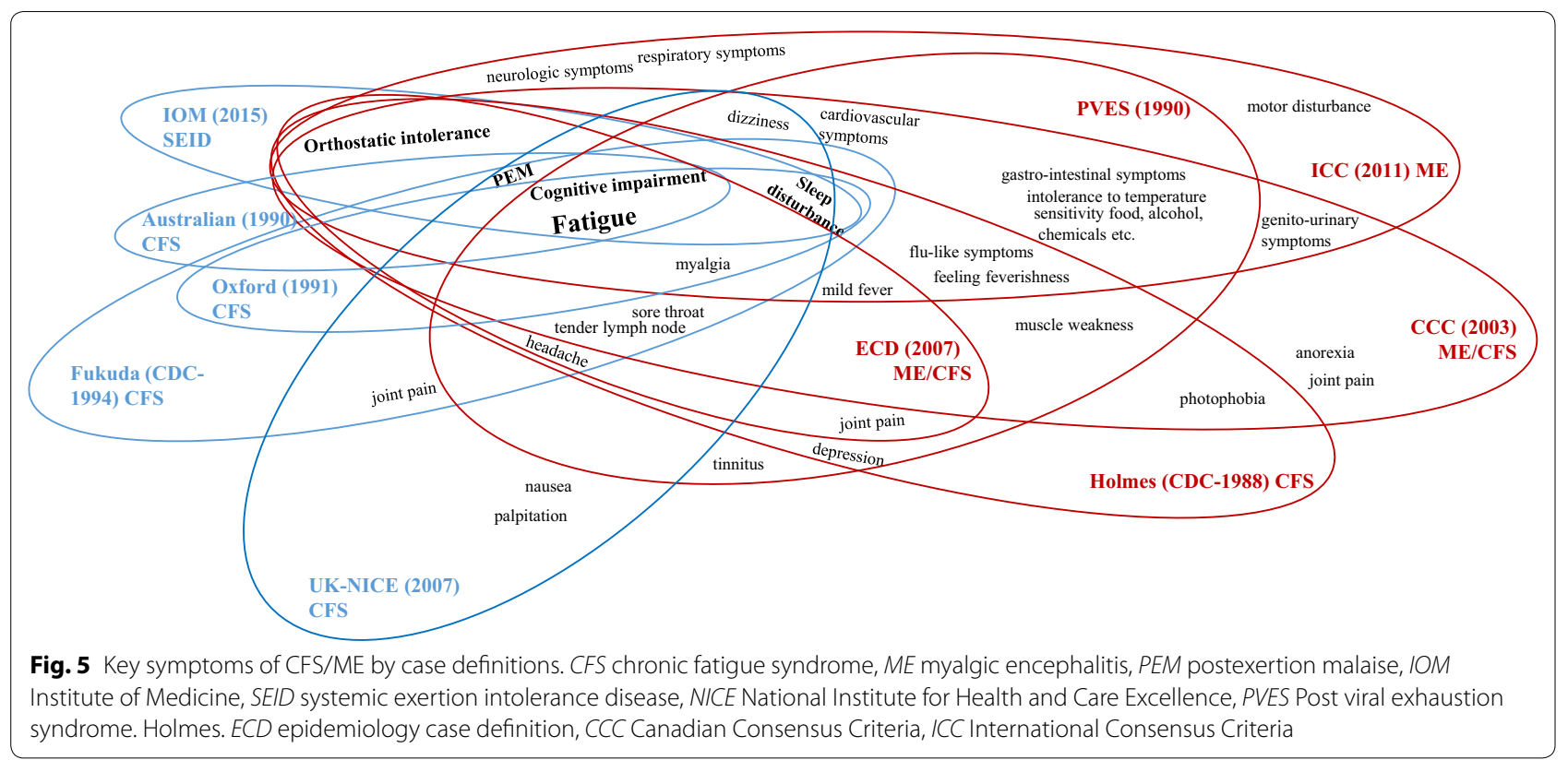

a new term, SEID (Systematic exertion intolerance disease), and its criteria were suggested by the IOM in 2015 [2].

As expected, the prevalence rates of CFS/ME differed according to the case definitions; there was an approximately sevenfold difference in the averaged prevalence of $0.34 \%$ based on the Holmes definition vs. $2.52 \%$ based on the Australian definition (Table 2). In general, the definitions could be categorized into two groups: the CDC-1994 [22], Australian [25], Oxford [24], IOM-SEID [2] and NICE definitions [29] vs. the Ramsay [21], Holmes [23], ICC 35], CCC [27], PVES [28], and ECD definitions [26]. These two groups overlap in requiring the symptom of cognitive impairment and share the general physical and neurologic symptoms; however, they differ in their inclusion or exclusion of more immune-, neuroendocrine-, and/or autonomic-related symptoms (Fig. 5). Accordingly, in our study, the prevalence determined with the CDC-1994, Australian, Oxford, NICE definitions were higher (range 1.46-2.52\%) than those determined using the definitions CCC, ECD, PVES, and Holmes definitions (range 0.03-0.34\%) [36-38] (Table 2, Fig. 5). Four studies that independently applied multiple case definitions to the same population all reported considerably higher prevalence based on the CDC-1994, Australian, and Oxford definitions than on the Holmes definition [16, 34, 37, 39].

The majority of the prevalence data (34 of total 56 data) were based on the CDC-1994 definition in our study, which found a mean prevalence of $1.46 \%$ and a meta-analysis result of $0.89 \%$ (Tables 2 and 3). Our mean prevalence result $(1.46 \%)$ is comparable to the results of previous review studies of CFS/ME prevalence that adopted the CDC-1994 definition [20, 40]. The pathophysiology of CFS/ME is still unclear; thus, the definition of this disorder is not yet conclusive. The CDC-1994 definition is criticized of the polythetic method that can select some individuals without the core symptoms of CFS [41, 42]. The most recent definition, SEID, is also said to be a problematic due to the possibility of including psychiatric illness [43]. This suggests a need for a rigorous diagnostic procedure with clear cut-off points and reasons for exclusions that anticipates the presence of subtypes of CFS/ME patients [20, 44], and the objective diagnostic parameters [45].

As expected, prevalence can also vary by study design. Among the 4 categories of diagnostic methods, the prevalence rate based on physician diagnosis was the lowest $(0.10 \%)$. The questionnaire-based interview without a medical test yielded the highest prevalence (2.03\%), while the addition of a medical test reduced the prevalence by approximately half a percentage point $(1.17 \%)$ (Table 2 ). A similar pattern was observed in the meta-analysis ( $1.14 \%$ vs. $0.95 \%$, Table 3 , Additional file 6$)$ and was also described in Johnston's review study [19]. In the clinical field, the final diagnosis of certain diseases is made by a physician on the basis of medical tests; accordingly, it is anticipated that only the questionnaire-derived CFS/ME prevalence is likely to be overestimated. On the other hand, there are concerns that physicians tended to deny the diagnosis or to not believe in CFS as a disease [46]. In addition, the complexity and rarity of the condition 
should be considered in terms of the diagnosis and management of CFS in general practice [47].

It is well-known genetic background and living environment are important factors in the development or progression of diseases [48]. CFS/ME was once considered a disease of the middle to upper classes that was mostly prevalent in the Caucasian population [49], although other studies have suggested that members of minority groups and lower economic classes are more prone to CFS/ME due to psychosocial and environmental risk factors such as lack of adequate nutrition, limited access to healthcare, and work-related stressors $[16,50-$ 52]. In this respect, it is of interest that some studies from different countries showed similar prevalence rates in similar settings; i.e., when the CDC-1994 was used with a medical test for a community-based general population, similar results were found for Nigeria $(0.28 \%$ for CFS, or $0.68 \%$ of CFS-like), the U.S. (0.60\% and $0.42 \%)$, and Korea $(0.61 \%)$ [50, 53-55] (Table 2). Additionally, the prevalence in specific populations, such as nurses and Gulf War veterans, seems to be slightly higher $(1.62 \%)$ than that in the general population (1.45\%) (Table 2); however, as others have argued, this difference could result from methodological inconsistencies [18].

In our results, women had CFS/ME prevalence approximately 1.5- to 2 fold higher than that of men, and this finding was consistent in all subgroups (Table 1,2). This gender difference in CFS/ME prevalence could be related to biological factors, primarily gender hormones and/or immunologic responses to environmental exposures [56, 57]. Some review studies reported a gender difference starting at puberty (approximately 13 years of age) in anticipation of hormonal or biochemical responses [48, $58,59]$. Our results showed a $0.89 \%(0.55 \%$ in the metaanalysis) prevalence in children and adolescents based on data from 6 studies (Tables 2 and 3). A Norwegian population-based study showed a 3.2-fold female predominance, and, interestingly, two age peaks for prevalent features in both gender: ages 10-19 and 30-39 years [59]. A further epidemiological study of biological changes according to those age peaks may support a rational for the gender differences. Furthermore, the greatest gender difference (females $1.94 \%$ vs. males $0.70 \%$ ) was shown in the pooled prevalence for the community population (Table 2). As described above, data for the communitybased studies were mainly conducted by using interviewbased methods (Table 1), and additionally, women are known to be more likely to report their complaints [60].

This study provides an updated review on the prevalence of CFS/ME but does not assess the accuracy of diagnosis. The limitations are the high heterogeneity of diagnostic tools and methods used; the lack of data based on some case definitions, such as ICC, CCC and SEID; the small number of studies in some subgroup analyses; and limited information on gender and age. Despite these limitations, we found that there was some possibility of under- or overestimation of the prevalence, particularly depending on the case definitions adopted. We observed a high heterogeneity in the reported prevalence; as estimated, the ranges for three extraction methodologies were $1.40 \%$ (95\% CI: $0.98-1.82$ ) for the averaged prevalence, $0.39 \%$ (95\% CI: $0.00-0.81)$ for the pooled prevalence and $0.68 \%$ (95\% CI: $0.48-0.97)$ for the metaanalysis. Recently, one study reported a $0.67 \%$ CFS or ME prevalence and a $0.12 \% \mathrm{ME}$ prevalence using large medical claims data with ICD (International Classification of Disease) codes [61]. Those results concur with our CFS/ ME prevalence findings of $0.68 \%$ for the entire dataset and 0.09 and $0.12 \%$ in the meta-analysis based on physician diagnosis and the Holmes definition, respectively. Thus, case definition and diagnostic methods are the factors with the greatest influence on the results, with data ranges that vary by approximately 5 - to tenfold. Following our study results, in addition to a proposal for a new diagnostic code [61, 62], a pattern recognition methods to subdivide CFS patients according to symptom clusters (e.g., specific phenotype features) with the adaption of objective measurement (e.g., two cardiopulmonary exercise tests, CPETs) were suggested for more empiric definition of the condition [44].

\section{Conclusions}

Taken together, our findings illustrated the prevalence of $\mathrm{CFS} / \mathrm{ME}$, providing comprehensive information that can serve as an essential reference for further studies of CFS/ ME. The overall estimated prevalence was $0.89 \%$ when based on the CDC-1994 definition and 1.14\% when diagnosed via interview, and there was an approximately 1.5 fold predominance of women; however, the prevalence rates varied according to the case definitions and diagnostic methods used by as much as tenfold.

\section{Supplementary information}

Supplementary information accompanies this paper at https://doi. org/10.1186/s12967-020-02269-0.

Additional file 1: Extracted raw data from the included studies.

Additional file 2: Meta-analysis of CFS/ME prevalence in community (A) and primary care $(B)$ settings

Additional file 3: Meta-analysis of the CFS/ME prevalence for children and adolescents (A) and specific populations (B).

Additional file 4: Meta-analysis of CFS/ME prevalence based on the CDC1994 case definition.

Additional file 5: Meta-analysis of CFS/ME prevalence based on the Holmes (A), Australian (B), Oxford (C), and other (D) definitions.

Additional file 6: Meta-analysis of CFS/ME prevalence by interview (A) and interview with medical test (B). 
Additional file 7: Meta-analysis of prevalence studies with diagnosis by physician determination (A) and review of medical records (B).

\section{Acknowledgements}

Not applicable.

\section{Authors' contributions}

E-JL was responsible for literature search, data collection, analysis, and drafting manuscript. Y-CA conducted meta-analysis using $R$ statistical program. C-GS was responsible for supervision of the study, and contributed supporting in writing the manuscript. E-SJ, S-WL, and S-HL peer reviewed the manuscript. All authors read and approved the final manuscript.

\section{Funding}

This research was supported by the National Research Foundation of Korea (NRF) funded bythe Oriental Medicine R\&D Project (NRF-2018R1A6A1A03025221).

\section{Availability of data and materials}

All data analyzed during this study are available in the public domain.

\section{Ethics approval and consent to participate}

Not applicable.

\section{Consent for publication}

Not applicable.

\section{Competing interests}

There are no potential conflicts of interest to disclose.

\section{Author details}

${ }^{1}$ Institute of Bioscience and Integrative Medicine, Department of Korean Medicine, Daejeon University, 62 Daehak-ro, Dong-gu, Daejeon, Republic of Korea. ${ }^{2}$ Department of Health Service Management, Daejeon University, 96-3 Yongun-dong, Dong-gu, Daejeon 300-716, Republic of Korea. ${ }^{3}$ Division of Future Medicine, Korean Institute of Oriental Medicine, Yuseong-daero, 1672 Daejeon, Republic of Korea. ${ }^{4}$ The Catholic University of Korea, Daejeon St. Mary Hospital, 64, Daeheung-ro, Jung-gu, Daejeon, Republic of Korea.

Received: 4 January 2020 Accepted: 14 February 2020

Published online: 24 February 2020

\section{References}

1. National Institutes of Health. ME/CFS. About ME/CFS. 2017 February 6, 2017 [cited 2019 July, 24th]. https://www.nih.gov/mecfs/about-mecfs.

2. Institute of medicine of the national academes, Beyond myalgic encephalomyelitis/chronic fatigue syndrome; Redefining an illness, Committee on the diagnostic criteria for ME/CFS, 2015, Institute of medicine: Washington, D.C.

3. Hvidberg MF, Brinth LS, Olesen AV, Petersen KD, Ehlers L. The healthrelated quality of life for patients with myalgic encephalomyelitis/chronic fatigue syndrome (ME/CFS). PLOS ONE. 2015;10(7):e0132421.

4. Pendergrast T, Brown A, Sunnquist M, Jantke R, Newton JL, Strand EB, Jason LA. Housebound versus nonhousebound patients with myalgic encephalomyelitis and chronic fatigue syndrome. Chronic IIIn. 2016;12(4):292-307.

5. Castro-Marrero J, Faro M, Zaragoza MC, Aliste L, de Sevilla TF, Alegre J. Unemployment and work disability in individuals with chronic fatigue syndrome/myalgic encephalomyelitis: a community-based cross-sectional study from Spain. BMC Public Health. 2019;19(1):840.

6. Crawley E. The epidemiology of chronic fatigue syndrome/myalgic encephalitis in children. Arch Dis Child. 2014;99(2):171-4.

7. Cleare AJ. The HPA axis and the genesis of chronic fatigue syndrome. Trends Endocrinol Metab. 2004;15(2):55-9.

8. Sorenson, M., N. Porter, L. Jason, A. Lerch, and H. Matthews, IL-8 Increased in Patients with CFS. Manuscript Submitted for Publication, 2011.
9. Chaves-Filho AJM, Macedo DS, de Lucena DF, Maes M. Shared microglial mechanisms underpinning depression and chronic fatigue syndrome and their comorbidities. Behav Brain Res. 2019;372:111975.

10. Nakatomi Y, Mizuno K, Ishii A, Wada Y, Tanaka M, Tazawa S, Onoe K, Fukuda S, Kawabe J, Takahashi K, Kataoka Y, Shiomi S, Yamaguti K, Inaba M, Kuratsune $H$, Watanabe $Y$. Neuroinflammation in patients with chronic fatigue syndrome/myalgic encephalomyelitis: an 11C-(R)-PK11195 PET study. J Nucl Med. 2014;55(6):945-50.

11. Montoya JG, Holmes TH, Anderson JN, Maecker HT, Rosenberg-Hasson Y, Valencia IJ, Chu L, Younger JW, Tato CM, Davis MM. Cytokine signature associated with disease severity in chronic fatigue syndrome patients. Proc Natl Acad Sci U S A. 2017;114(34):E7150-8.

12. Esfandyarpour R, Kashi A, Nemat-Gorgani M, Wilhelmy J, Davis RW. A nanoelectronics-blood-based diagnostic biomarker for myalgic encephalomyelitis/chronic fatigue syndrome (ME/CFS). Proc Nat Acad Sci. 2019;116(21):10250-7.

13. Smith ME, Haney E, McDonagh M, Pappas M, Daeges M, Wasson N, Fu R, Nelson HD. Treatment of myalgic encephalomyelitis/chronic fatigue syndrome: a systematic review for a national institutes of health pathways to prevention workshop. Ann Intern Med. 2015;162(12):841-50.

14. GBD 2016 Multiple Sclerosis Collaborators. Global, regional, and national burden of multiple sclerosis 1990-2016: a systematic analysis for the Global Burden of Disease Study 2016. Lancet Neurol. 2019;18(3):269-85.

15. Gibofsky A. Overview of epidemiology, pathophysiology, and diagnosis of rheumatoid arthritis. Am J Manag Care. 2012;18(13 Suppl):S295-302.

16. Wessely S, Chalder T, Hirsch S, Wallace P, Wright D. The prevalence and morbidity of chronic fatigue and chronic fatigue syndrome: a prospective primary care study. Am J Pub Health. 1997;87(9):1449-55.

17. Jason LA, Sunnquist M, Brown A, McManimen S, Furst J. Reflections on the Institute of Medicine's systemic exertion intolerance disease. Pol Arch Med Wewn. 2015;125(7-8):576-81.

18. Ranjith G. Epidemiology of chronic fatigue syndrome. Occup Med (Lond). 2005;55(1):13-9.

19. Johnston S, Brenu EW, Staines D, Marshall-Gradisnik S. The prevalence of chronic fatigue syndrome/myalgic encephalomyelitis: a meta-analysis. Clin Epidemiol. 2013;5:105-10.

20. Brurberg KG, Fonhus MS, Larun L, Flottorp S, Malterud K. Case definitions for chronic fatigue syndrome/myalgic encephalomyelitis (CFS/ME): a systematic review. BMJ Open. 2014;4(2):e003973.

21. Ramsay AM. Myalgic encephalomyelitis and postviral fatigue states: the saga of royal free disease. 2nd ed. London, UK: Gower Publishing Corporation; 1988.

22. Fukuda K, Straus SE, Hickie I, Sharpe MC, Dobbins JG, Komaroff A. The chronic fatigue syndrome: a comprehensive approach to its definition and study. Ann Intern Med. 1994;121(12):953-9.

23. Holmes GP, Kaplan JE, Gantz NM, Komaroff AL, Schonberger LB, Straus $\mathrm{SE}$, et al. Chronic fatigue syndrome: a working case definition. Ann Intern Med. 1988;108:387-9.

24. Sharpe MC, Archard LC, Banatvala JE, Borysiewicz LK, Clare AW, David A, et al. A report-chronic fatigue syndrome: guidelines for research. J R Soc Med. 1991;84:118-21.

25. Lloyd AR, Hickie I, Boughton CR, Spencer O, Wakefield D. Prevalence of chronic fatigue syndrome in an Australian population. Med J Aust. 1990;153(9):522-8.

26. Osoba T, Pheby D, Gray S, Nacul L. The development of an epidemiological definition for myalgic encephalomyelitis/chronic fatigue syndrome. J Chronic Fatigue Syndr. 2007;14(4):61-84.

27. Carruthers BM, Jain AK, De Meirleir KL, Peterson DL, Klimas NG, Lerner AM, et al. Myalgic encephalomyelitis/chronic fatigue syndrome: clinical working case definition, diagnostic and treatment protocols. J Chronic Fatigue Syndr. 2003;11(1):7-115.

28. Ho-Yen DO. Patient management of post-viral fatigue syndrome. Br J Gen Pract. 1990;40:37-9.

29. National Collaborating Center for Primary Care. NICE clinical guideline 53. Chronic fatigue syndrome/myalgic encephalomyelitis (or encephalopathy): diagnosis and management of CFS/ME in adults and children, Royal college of general practitioners, 2007, National Institute for Health and Care Excellence: London.

30. Higgins JP, Thompson SG. Quantifying heterogeneity in a meta-analysis. Stat Med. 2002;21(11):1539-58. 
31. Walker E, Hernandez AV, Kattan MW. Meta-analysis: its strengths and limitations. Cleve Clin J Med. 2008;75(6):431-9.

32. Shi J, Shen J, Xie J, Zhi J, Xu Y. Chronic fatigue syndrome in Chinese middle-school students. Medicine (Baltimore). 2018;97(4):e9716.

33. Price RK, North CS, Wessely S, Fraser VJ. Estimating the prevalence of chronic fatigue syndrome and associated symptoms in the community. Public Health Rep. 1992;107(5):514-22.

34. Líndal E, Stefánsson JG, Bergmann S. The prevalence of chronic fatigue syndrome in Iceland - a national comparison by gender drawing on four different criteria. Nord J Psychiatry. 2002;56(4):273-7.

35. Carruthers BM, van de Sande MI, De Meirleir KL, Klimas NG, Broderick G, Mitchell T, et al. Myalgic encephalomyelitis: International Consensus Criteria. J Intern Med. 2011;270(4):327-38.

36. Ho-Yen DO, McNamara I. General practitioners' experience of the chronic fatigue syndrome. Br J Gen Pract. 1991;41(349):324-6.

37. Nacul LC, Lacerda EM, Pheby D, Campion P, Molokhia M, Fayyaz S, Leite JC, Poland F, Howe A, Drachler ML. Prevalence of myalgic encephalomyelitis/chronic fatigue syndrome (ME/CFS) in three regions of England: a repeated cross-sectional study in primary care. BMC Med. 2011;9(1):91.

38. Collin SM, Norris T, Nuevo R, Tilling K, Joinson C, Sterne JA, Crawley E. Chronic fatigue syndrome at age 16 years. Pediatrics. 2016;137(2):e20153434.

39. Bates DW, Schmitt W, Buchwald D, Ware NC. Prevalence of fatigue and chronic fatigue syndrome in a primary care practice. JAMA Int Med. 1993;153(24):2759.

40. Son C. Review of the prevalence of chronic fatigue worldwide. J Korean Oriental Med. 2012;33(2):25-33.

41. Morris G, Maes M. Case definitions and diagnostic criteria for myalgic encephalomyelitis and chronic fatigue syndrome: from clinicalconsensus to evidence-based case definitions. Neuro Endocrinol Lett. 2013;34(3):185-99.

42. Jason LA, Sunnquist M, Brown A, Reed J. Defining essential features of myalgic encephalomyelitis and chronic fatigue syndrome. J Hum Behav Soc Environ. 2015;25(6):657-74.

43. Bested AC, Marshall LM. Review of myalgic encephalomyelitis/chronic fatigue syndrome: an evidence-based approach to diagnosis and management by clinicians. Rev Environ Health. 2015;30(4):223-49.

44. Twisk FN. Replacing Myalgic Encephalomyelitis and chronic fatigue syndrome with systemic exercise intolerance disease is not the way forward. Diagnostics. 2016;6(1):10.

45. Twisk F. An accurate diagnosis of myalgic encephalomyelitis and chronic fatigue syndrome requires strict clinical case definitions and objective test methods. J Med Diagn Meth. 2017;6:249.

46. Bazelmans E, Vercoulen JH, Swanink CM, Fennis JF, Galama JM, van Weel C, van der Meer JW, Bleijenberg G. chronic fatigue syndrome and primary fibromyalgia syndrome as recognized by GPS. Fam Pract. 1999;16(6):602-4.

47. Bayliss K, Riste L, Band R, Peters S, Wearden A, Lovell K, Fisher L, ChewGraham CA. Implementing resources to support the diagnosis and management of chronic fatigue syndrome/myalgic encephalomyelitis (CFS/ ME) in primary care: a qualitative study. BMC Fam Pract. 2016;17:1-11.

48. Chu L, Valencia IJ, Garvert DW, Montoya JG. Onset patterns and course of myalgic encephalomyelitis/chronic fatigue syndrome. Front Pediatr. 2019;7:12

49. Friedberg F. An Overview of Psychometric Assessment. J Chronic Fatigue Syndrome. 1998;5:161-71.

50. Njoku MGC, Jason LA, Torres-Harding SR. The prevalence of chronic fatigue syndrome in Nigeria. J Health Psychol. 2007;12(3):461-74.

51. Bayliss K, Riste L, Fisher L, Wearden A, Peters S, Lovell K, Chew-Graham C. Diagnosis and management of chronic fatigue syndrome/myalgic encephalitis in black and minority ethnic people: a qualitative study. Prim Health Care Res Dev. 2014;15(2):143-55.

52. Bierl C, Nisenbaum R, Hoaglin DC, Randall B, Jones A-B, Unger ER, Reeves WC. Regional distribution of fatiguing illnesses in the United States: a pilot study. Popul Health Metr. 2004;2(1):1.

53. Jason LA, Richman JA, Rademaker AW, Jordan KM, Plioplys AV, Taylor RR, McCready W, Huang CF, Plioplys S. A community-based study of chronic fatigue syndrome. Arch Intern Med. 1999;159(18):2129-37.

54. Reyes M, Nisenbaum R, Hoaglin DC, Unger ER, Emmons C, Randall B, Stewart JA, Abbey S, Jones JF, Gantz N, Minden S, Reeves WC. Prevalence and incidence of chronic fatigue syndrome in Wichita, Kansas. Arch Intern Med. 2003;163(13):1530-6.

55. Kim CH, Shin HC, Won CW. Prevalence of chronic fatigue and chronic fatigue syndrome in Korea: community-based primary care study. J Korean Med Sci. 2005;20(4):529-34.

56. van Vollenhoven RF. Sex differences in rheumatoid arthritis: more than meets the eye. BMC Med. 2009:7:12.

57. Albrecht K. Gender-specific differences in comorbidities of rheumatoid arthritis. Z Rheumatol. 2014;73(7):607-14.

58. Piccini $P$, Montagnani $C$, de Martino M. Gender disparity in pediatrics: a review of the current literature. Italian J Pediatr. 2018;44(1):1.

59. Bakken IJ, Tveito K, Gunnes N, Ghaderi S, Stoltenberg C, Trogstad L, Haberg SE, Magnus P. Two age peaks in the incidence of chronic fatigue syndrome/myalgic encephalomyelitis: a population-based registry study from Norway 2008-2012. BMC Med. 2014;12:167.

60. Lawrie SM, Pelosi AJ. Chronic fatigue syndrome in the community prevalence and associations. Br J Psychiatry. 1995;166(6):793.

61. Valdez AR, Hancock EE, Adebayo S, Kiernicki DJ, Proskauer D, Attewell JR, Bateman L, DeMaria A Jr, Lapp CW, Rowe PC, Proskauer C. Estimating prevalence, demographics, and costs of ME/CFS using large scale medical claims data and machine learning. Front Pediatr. 2018;6:412.

62. National Center for Health Statistics. ICD-10 Coordination and Maintenance Committee Meeting, Diagnosis Agenda Part 2; 2018 [cited 2019 July, 27th]. https://www.cdc.gov/nchs/data/icd/Topic_packe t_Sept 2018 part2.pdf.

63. Rusu C, Gee ME, Lagacé C, Parlor M. Chronic fatigue syndrome and fibromyalgia in Canada: prevalence and associations with six health status indicators. Health Promot. 2015;35(1):3-11.

64. Vincent A, Brimmer DJ, Whipple MO, Jones JF, Boneva R, Lahr BD, Maloney E, Sauver JL, Reeves WC. Prevalence, incidence, and classification of chronic fatigue syndrome in Olmsted County, Minnesota, as estimated using the Rochester Epidemiology Project. In Mayo Clinic Proc. 2012;87(12):1145-52.

65. Bhui KS, Dinos S, Ashby D, Nazroo J, Wessely S, White PD. Chronic fatigue syndrome in an ethnically diverse population: the influence of psychosocial adversity and physical inactivity. BMC Med. 2011;9:26.

66. Hamaguchi M, Kawahito Y, Takeda N, Kato T, Kojima T. Characteristics of chronic fatigue syndrome in a Japanese community population. Clin Rheumatol. 2011;30(7):895-906.

67. Nijhof SL, Maijer K, Bleijenberg G, Uiterwaal CSPM, Kimpen JLL, van de Putte EM. Adolescent chronic fatigue syndrome: prevalence, incidence, and Morbidity. Pediatrics. 2011;127(5):958.

68. van't Leven M, Zielhuis GA, van der Meer JW, Verbeek AL, Bleijenberg G. Fatigue and chronic fatigue syndrome-like complaints in the general population. Eur J Pub Health. 2010;20(3):251-7.

69. Cho HJ, Menezes PR, Hotopf M, Bhugra D, Wessely S. Comparative epidemiology of chronic fatigue syndrome in Brazilian and British primary care: prevalence and recognition. Br J Psychiatry. 2009;194(2):117-21.

70. Kim S. Prevalence of chronic widespread pain and chronic fatigue syndrome in young Korean adults. J Musculoskeletal Pain. 2008;16(3):149-53.

71. Kim SH, Lee K, Lim HS. Prevalence of chronic widespread pain and chronic fatigue syndrome in Korean livestock raisers. J Occup Health. 2008;50(6):525-8.

72. Reeves WC, Jones JF, Maloney E, Heim C, Hoaglin DC, Boneva RS, Morrissey M, Devlin R. Prevalence of chronic fatigue syndrome in metropolitan, urban, and rural Georgia. Popul Health Metr. 2007;5:5.

73. Paralikar V, Agashe M, Oke M, Dabholkar H, Abouihia A, Weiss MG. Prevalence of clinically significant functional fatigue or weakness in specialty outpatient clinics of Pune. India. J Indian Med Assoc. 2007;105(8):424-6.

74. Rimes KA, Ashcroft J, Bryan L, Chalder T. Emotional suppression in chronic fatigue syndrome: experimental study. Health Psychol. 2016;35(9):979-86.

75. Furberg H, Olarte M, Afari N, Goldberg J, Buchwald D, Sullivan PF. The prevalence of self-reported chronic fatigue in a US twin registry. J Psychosom Res. 2005;59(5):283-90.

76. Evengard B, Jacks A, Pedersen NL, Sullivan PF. The epidemiology of chronic fatigue in the Swedish Twin Registry. Psychol Med. 2005;35(9):1317-26

77. Yiu YM, Qiu MY. A preliminary epidemiological study and discussion on traditional Chinese medicine pathogenesis of chronic fatigue syndrome in Hong Kong. Zhong Xi Yi Jie He Xue Bao. 2005;3(5):359-62. 
78. Huibers MJ, Kant IJ, Swaen GM, KasI SV. Prevalence of chronic fatigue syndrome-like caseness in the working population: results from the Maastricht cohort study. Occup Environ Med. 2004;61(5):464-6.

79. Jones JF, Nisenbaum R, Solomon L, Reyes M, Reeves WC. Chronic fatigue syndrome and other fatiguing illnesses in adolescents: a populationbased study. J Adolesc Health. 2004;35(1):34-40.

80. Farmer A, Fowler T, Scourfield J, Thapar A. Prevalence of chronic disabling fatigue in children and adolescents. Br J Psychiatry. 2004;184:477-81.

81. Chalder T, Goodman R, Wessely S, Hotopf M, Meltzer H. Epidemiology of chronic fatigue syndrome and self reported myalgic encephalomyelitis in 5-15 year olds: cross sectional study. BMJ. 2003;327(7416):654-5.

82. McCauley LA, Joos SK, Barkhuizen A, Shuell T, Tyree WA, Bourdette DN. Chronic fatigue in a population-based study of Gulf War veterans. Arch Environ Health. 2002;57(4):340-8.

84. Ji JD, Choi YS, Chun BC, Choi SJ, Lee YH, Song GG. The prevalence and clinical manifestations of chronic fatigue syndrome in persons who visited health management center. Korean J Med. 2000;59(5):529-34.

85. Ji JD, Choi SJ, Lee YH, Song GG. Incidence and clinical manifestations of chronic fatigue in Korea. Korean Journal of Medicine. 1999;56(14):738-44.

86. Jason LA, Wagner L, Rosenthal S, Goodlatte J, Lipkin D, Papernik M, Plioplys S, Plioplys AV. Estimating the prevalence of chronic fatigue syndrome among nurses. Am J Med. 1998;105(3/1):3-91.

87. Steele L, Dobbins JG, Fukuda K, Reyes M, Randall B, Koppelman M, Reeves WC. The epidemiology of chronic fatigue in San Francisco. Am J Med. 1998;105(3):83S-90S.
88. Fukuda K, Dobbins JG, Wilson L, Dunn RA, Wilcox K, Smallwood D. An epidemiologic study of fatigue with relevance for the chronic fatigue syndrome. J PsychiatryRes. 1997;31(1):19-29.

89. Versluis RG, de Waal MW, Opmeer C, Petri H, Springer MP. Prevalence of chronic fatigue syndrome in 4 family practices in Leiden. Ned Tijdschr Geneeskd. 1997;141(31):1523-6.

90. Minowa M, Jiamo M. Descriptive epidemiology of chronic fatigue syndrome based on a nationwide survey in Japan. J Epidemiol. 1996:6(2):75-80.

91. Buchwald D, Umali P. Chronic fatigue and the chronic fatigue syndrome: prevalence in a Pacific Northwest health care. Ann Intern Med. 1995;123(2):81.

92. Jason LA, Taylor R, Wagner L, Holden J, Ferrari JR, Plioplys AV, Plioplys S, Lipkin D, Papernik M. Estimating rates of chronic fatigue syndrome from a community-based sample: a pilot study. Am J Community Psychol. 1995;23(4):557-68

93. Jason LA, Fitzgibbon G, Taylor SL, Johnson S, Salina D. Strategies in identifying people with chronic fatigue syndrome. J Commun Psychol. 1993;21(4):339-44.

\section{Publisher's Note}

Springer Nature remains neutral with regard to jurisdictional claims in published maps and institutional affiliations.
Ready to submit your research? Choose BMC and benefit from:

- fast, convenient online submission

- thorough peer review by experienced researchers in your field

- rapid publication on acceptance

- support for research data, including large and complex data types

- gold Open Access which fosters wider collaboration and increased citations

- maximum visibility for your research: over $100 \mathrm{M}$ website views per year

At BMC, research is always in progress.

Learn more biomedcentral.com/submissions 